\title{
Differences in innovativeness, proactiveness and competitive aggressiveness in relation to entrepreneurial motives
}

\author{
Ludmila Kozubíková \\ Tomas Bata University in Zlin \\ Crech Republic \\ kozubikova@fame.utb.cz.
}

\section{Gabriela Sopková}

University of Economics in Bratislava

Slovak Republic

gabika.sopkova@gmail.com

\section{Vladimír Krajčík}

Pan-European University in Bratislava

Slovak Republic

krajcik@vspp.cz.

\section{Ladislav Tyll}

University of Economics in Prague

Caech Republic

ladislav.tyll@vse.cz.

Abstract. Motivation of entrepreneurs must be appropriate to the level of risk they are facing in their businesses. Some entrepreneurs can perceive profit or financial motivation as a subsidiary motive and can start their own business with non-financial motives, e.g., apprehending business as a mission. The aim of this article is to identify the relationship between entrepreneurial motives and the selected constructs of entrepreneurial orientation (innovativeness, proactiveness and competitive aggressiveness) on the case study of small and medium-sized enterprises (SMEs) in Czech Republic. We have analyzed the data collected in 2015 from 1141 SMEs in 14 regions of Czech Republic. For the purposes of this article we focused on the motives for doing business, which were analyzed for the sample as a whole and also for two selected groups of the respondents. The first group (330 respondents) consisted of entrepreneurs who featured money as the most important motive for starting up a business, while the second group (251 respondents) consisted of those entrepreneurs who featured their life mission as the main reason for starting a business. The main results of 
our paper confirm the existence of statistically significant differences in innovativeness, proactiveness and competitive aggressiveness between the entrepreneurs motivated by money and those motivated by mission. Regardless the entrepreneurial motives the vast majority of the surveyed entrepreneurs consider innovativeness and proactiveness to be important for their companies. On the other hand, most of them do not realize aggressive activities against the competition they are facing.

Keywords: entrepreneurial motives, innovativeness, proactiveness, competitive aggressiveness, mission, money.

JEL Classification: L26

\section{INTRODUCTION}

Since small and medium-sized enterprises (SMEs) play an important role in Czech economy, it is not surprising that the status of these entrepreneurs and the problems related to their existence are vitally important and widely discussed. Entrepreneurial orientation (EO) of SMEs presents a possible way of increasing their performance and therefore many authors deal with this topic (Belás \& Sopková, 2016a; Belás \& Sopková, 2016b; Vojtovič, 2016; Covin \& Wales, 2011; Hudakova, Buganova \& Dvorsky, 2015; Kraus, 2013; Moreno \& Casillas, 2008; Lim \& Envick; 2013, among others). For the development of SMEs high-quality business environment creates favorable conditions. Not only economic criteria, but also social, education and other factors are playing an important role in this process (Ključnikov, Belás, Kozubíková \& Paseková, 2016; Dúbravská, Mura, Kotulič, \& Novotný, 2015; Virglerová, Dobes \& Vojtovic, 2016). With the rapid development of market-oriented economy, SMEs more intensively face fierce market competition (Belás, Ključnikov, Vojtovič \& Sobeková-Májková, 2015).

The nature of SMEs as such makes it inevitable to take into account the personality of an entrepreneur as a factor significantly influencing the status and the success of SMEs. Many authors focus their researches on suitable personality traits of entrepreneurs (Beugelsdijk \& Noorderhaven, 2005; Caliendo, Fossen \& Kritikos, 2014; Frese \& Gielnik, 2014; Hines, 2004; Kozubíková, Belás, Ključnikov, \& Virglerová, 2015; Belás, Bartoš, Ključnikov, \& Doležal, 2015).

The motives to become an entrepreneur can be different, and include propensity for risk, desire to earn more money in other ways than in paid employment, search for a better work-life balance, need to seek self-employment, passion, need to fulfill a mission and others.

Due to the vital importance of SME sector for Czech economy's performance we wanted to find out more on entrepreneurial motives within Czech SME sector for better understanding and improvement of conditions for start-ups in relation to the selected constructs of EO (innovativeness, proactiveness and competitive aggressiveness) with their better entrepreneurial behavior increasing performance too. We have found that there is little information on entrepreneurial motives and EO in the context of Czech SME sector, except the information available from the Association of SMEs of Czech Republic. The study aims to reveal the differences in the attitudes to innovativeness, proactiveness and competitive aggressiveness in relation to two different motives of doing business - money and mission. 


\section{LITERATURE REVIEW}

According to Zortea-Johnston, Darroch and Matear (2012) EO should drive the market through the new product development, product innovation and creation of the competitive advantages in the market.

Our research deals with three important components of EO. Existing findings on this research field show that EO is usually understood as a five-dimensional construct consisting of innovativeness, risk-taking, proactiveness, autonomy and competitive aggressiveness. The most widely used definition of the $\mathrm{EO}$ is based on the work of Miller (1983), further developed by Covin and Slevin (1989) and many others (Rauch, Wiklund, Lumpkin \& Frese, 2009; Wiklund \& Shepherd, 2003) and extended by Lumpkin and Dess (1996). Miller (1983) introduced original three dimensional concept of innovativeness, proactiveness and risk-taking. He provided a useful starting point. Lumpkin and Dess (1996) extended Miller's original model by additional two constructs - autonomy and competitive aggressiveness. They focused on an effective combination of all five constructs (p. 136).

Global economy creates an enormous pressure on the companies (Betakova, Haviernikova \& Dvorsky, 2014). SMEs must be able to quickly react on the new conditions and opportunities arising in the market and must be able to innovate their technologies and products. As Zastempowski and Przybylska (2016) state the growing impact of globalization and the rapid pace of technological advances are contributing to the development of new types of linkages between the world's economies. This fact influences many fields of entrepreneurial life. According to Zamecnik and Vystupova (2012) currently, we are seeing the growth in significance and emphasis of a range of new success factors (quality, time, costs and customer satisfaction- i.e. utility) - for the time being, under-used in Controlling.

Innovative company can be understood as a firm tending to innovate or introduce something new or different. It reflects the tendency of companies to promote new ideas, experiments and creative processes. (Moreno \& Casillas, 2008).

Innovativeness is an important component of the $\mathrm{EO}$, because it reflects the important means by which the companies can pursue new opportunities. Innovativeness of the company may take several forms. In the broadest sense, it may occur along a continuum from a simple willingness to either try a new product line or experiment with a new advertising venue, to a passionate commitment to master the latest in new products or technological advances (Lumpkin \& Dess, 1996, p. 143).

According to Laforet (2013) small companies are more suitable for innovation than the mediumsized companies, because they are more flexible and they can adapt to any market changes with new product innovation.

If proactiveness is understood as "acting in anticipation of future problems, needs or changes", as such it may be crucial to an EO because it suggests a forward-looking perspective that is accompanied by innovative or new-venturing activity. Indeed proactiveness concerns the importance of initiative in the entrepreneurial process. (Lumpkin \& Dess, 1996).

Findings of Avlonitis and Salavou (2007) show that proactiveness contrary to risk-taking is found to be an important contributor to the performance of new products. The evidence shows that active and passive entrepreneurs differ significantly in one dimension of product innovativeness, namely new product uniqueness.

Based on the results of the research by Kraus, Rigtering, Hughes and Hosman (2012) we can state that proactiveness is significantly and positively associated with company's performance.

Competitive aggressiveness captures the distinct idea of "beating competitors to the punch" suggested by Miller's (1983) definition of an entrepreneurial company. It refers to the type of intensity and head-tohead posturing that new entrants often need to compete with existing rivals (Lumpkin \& Dess, 1996). It has been suggested that competitive strategy mediates the EO-performance relationship: competitive 
strategy is an intermediate variable between EO and performance, in the sense that companies with a greater EO will tend to develop certain types of strategies' and will influence performance differently (Moreno \& Casillas, 2008).

Competitive strategy adds content to EO and channels it (similar to how boxing training and tactics channels a boxer's aggressiveness). In other words, $\mathrm{EO}$ would not be sufficient for company performance without a competitive strategy (Ireland, Hitt \& Sirmon, 2003).

Although proactiveness is closely related to competitive aggressiveness, there is an important distinction between it and proactiveness. Proactiveness refers to how a company relates to market opportunities in the process of new entry, so it is to influence trends and even create demand. Competitive aggressiveness refers to how companies relate to competitors. (Lumpkin \& Dess, 1996)

The effort to explore business motives is understandable because a closer understanding of motivations can contribute to a better understanding of entrepreneurial behaviour (Boada-Grau, SánchezGarcía, Viardot, Boada-Cuerva \& Vigil-Colet, 2016).

For introducing existing knowledge on entrepreneurial motivation we present several opinions of different authors. It is possible to find a wide range of entrepreneurial motivations ranging from the economic motivations such as financial goals (Pinfold, 2001) to the non-economic, e. g. independence (Williams, 2009), autonomy (Lumpkin, Cogliser, \& Schneider, 2009), being one’s boss (Mattis, 2000), or seeking a challenge (Petrakis, 2007). In comparison Robichaud, Cachon and Haq (2010) also define frustration at working in a certain organization, the need for more job flexibility, the imbalance between work and leisure as the motives. In their study they revealed that primary reasons for owning a company in Canadian sample of female small companies were personal satisfaction and growth, to have fun and to prove they could do it.

According to Rey-Marti, Porcar and Mas-Tur (2015) in recent years several studies are showing that business expansion predominantly depends on company owners' motives, attitudes and intentions towards the future. They state that women's risk aversion, lack of faith in own abilities, and desire of a suitable work-life balance obviously limit women's decisions to expand their business. They have found out that two motives seem to have a special relationship with a company's likelihood of survival. The first is women entrepreneurs' propensity for risk. The second is the need to strike a work-life balance. This motive seems to have a positive relationship with non-survival and a negative relationship with business success. In other words, women who decide to launch a business because they seek to combine work and family commitments have lower chances of achieving medium-term business survival. In contrast, if their motive is to assume business risks, their success rate is higher.

During the study of existing opinions on entrepreneurial motive and EO we have revealed that entrepreneurial motivation can significantly influence entrepreneurial behavior realized by innovativeness, proactiveness a and competitive aggressiveness and at the same time we have not found enough studies on this relationship in the Czech Republic. It has motivated us to deal with this topic in more details.

Relationship lending, the most common techniques for lending to small firms, is based on the "soft" information which is accessible by keeping a close relationship with the client. Alternatively, there exist transaction-based lending techniques, those are mainly based on the "hard" information about the businesses. For example, financial statements based lending, asset based lending and credit scoring (Petersen \& Rajan, 2002). Researches dealing with the soft information generation and bank lending efficiency argue that the soft information collection and careful examination of the information can increase the lending efficiency of the bank that can positively affect the small business access to credit (D'Aurizio et al., 2015). On the other hand, empirical results show that commercial banks can improve the credit rating model by including the relationship lending qualitative (soft) information of the borrower in 
the rating process, and that focus only on the hard financial information can be misleading (Dolezal et al., 2015).

\section{METHODOLOGY}

In order to reach the main objective of the article (to identify and quantify the relationship between the characteristics of entrepreneurs (innovativeness, proactivity, aggressiveness) among the entrepreneurs whose motive for starting a business are money in comparison to the entrepreneurs whose motive was a perception of doing business as their mission) we have defined three basic areas of the research: innovativeness (statistical hypotheses - H1A, H1B), proactiveness $(\mathrm{H} 2 \mathrm{~A}, \mathrm{H} 2 \mathrm{~B})$ and aggressiveness to competitors (H3A, H3B) and formulated the following statistical hypotheses:

H1A: There are statistically significant differences between the selected groups of entrepreneurs in their own concept of the enterprise as an innovator.

H1B: There are no statistically significant differences between the selected groups of entrepreneurs in the affirmative reactions on the claim that the company produces new products (goods) or services.

H2A: More than three quarters of all entrepreneurs agree with the statement that their company is trying to use social changes as their advantage over the competition, regardless of the motive for starting a business.

H2B: There are no statistically significant differences between the selected groups of entrepreneurs in the affirmative reactions on the claim that the company is trying to seize the initiative in order to beat the competition.

H3A: There are no statistically significant differences between the selected groups of entrepreneurs in the affirmative reactions on the claim that their company has a reputation of an aggressive enterprise.

H3B: There are statistically significant differences between the selected groups of entrepreneurs in presenting the opinion that the activities of their company in relation to their competitors are aggressive.

In the first step, we obtained an electronic database of 1,141 SMESs from 14 regions of the Czech Republic (basic data set). The data were collected by the method of online questioning. At first we addressed 1,650 randomly selected SMEs from the Albertina database using the contact included in the database (email, phone, web-site) with a request to the appropriate representative of the management (owner, managing director, director, responsible managing employee) to complete the questionnaire on the presented hyperlink. The questionnaire consisted of 52 questions. In this context, in the first nine questions the structure of the respondents in relation to their education, gender, age, the residency and size of a firm, the length and area of conducting business, motives for starting a business and the most important characteristics of entrepreneur were analyzed. The rest of the questions were scale questions on a 1-5 scale (1-totally agree, 2 agree 3 do not hold a position, 4-disagree, 5 completely disagree) focused on five elements of EO (innovativeness, proactiveness, risk taking, autonomy and competitive aggressiveness). Each of the construct of $\mathrm{EO}$ were verified at least by 3 questions.

For the purpose of this paper we have focused on a question of motivation of the entrepreneur for starting a business in relation to innovativeness, proactiveness and competitive aggressiveness. The most common answers to the question on motives were: money, perception of doing business as a mission, independence, self-realization, but also a unique theme of the change of the political regime in 1989.For this reason we have selected only answers of 581 respondents from the basic sample (1,141 respondents) who selected money or doing business as their mission as a motive for starting a business.

In order to evaluate the defined statistical hypotheses needed to fulfill the objectives of the paper we used such methods of descriptive statistics, needed for the Z-score calculation. Contingency intensity was measured using the Pearson coefficient of contingency. Statistical hypotheses were adopted or rejected on 
the pre-set level of significance (limit of the hypotheses adoption) with p-value of 0.05 . For identifying the statistically significant differences in the responses between the selected groups according to the statistical character of motivation for doing business Z-score was applied. P-value of the standardized normal distribution was used to evaluate the Z-score parameters. Conditions for Z-test (normal distribution of the statistical features and a large range of sample) were met. Calculations were made through the sophisticated statistical software called SPSS Statistics.

\section{EMPIRICAL RESULTS AND DISCUSSION}

From the total number of 1141 respondents by using the simple method of sorting according to the selected statistical characteristic of motive for starting a business, we have selected a sample of 581 enterprises, who marked either money or mission as an answer. The structure of the selected statistical sample was as follows: money as the motive for starting a business was reported in 330 cases $(29 \%$ of 1141 respondents), there were 260 males and 70 females, 105 respondents with university education, 225 respondents with the other levels of education (highly educated or highly educated without graduation). The age structure was as follows: 102 of the entrepreneurs were younger than 35 years, 100 of them was between 36 and 45 years, and 128 respondents were over 45 years old. Mission as a motive reported in 251 cases (22\% of 1141 respondents), where 179 were males, 72 females, 106 had university education and 145 the other level of education (higher education or higher education without graduation). 67 respondents were under 35, 66 of them were between 36 and 45 years, and 118 respondents were over 45 years old.

Table 1 shows the results of the attitude of the company to their own image of the innovative company, sorted by the selected motives for starting a business (money and mission).

Table 1

My company has an image of an innovator

\begin{tabular}{|c|c|c|c|c|}
\hline \multirow{2}{*}{ Innovativeness } & \multicolumn{2}{|c|}{ Motive for starting a business } & \multirow{2}{*}{ Z-score } & \multirow{2}{*}{$\begin{array}{l}\text { Z-score } \\
\text { p-value }\end{array}$} \\
\hline & Money & Mission & & \\
\hline \multirow[b]{2}{*}{ Completely agree: $7 \%$ of the companies } & 21 & 22 & \multirow[b]{2}{*}{-1.095} & \multirow[b]{2}{*}{0.271} \\
\hline & $6 \%$ & $8.9 \%$ & & \\
\hline \multirow{2}{*}{$\begin{array}{c}\text { Agree: } \\
38 \% \text { of the companies }\end{array}$} & 100 & 118 & \multirow{2}{*}{-4.12} & \multirow{2}{*}{0.000} \\
\hline & $30 \%$ & $47 \%$ & & \\
\hline \multirow{2}{*}{$\begin{array}{l}\text { Take no position: } \\
33 \% \text { of the companies }\end{array}$} & 115 & 75 & \multirow{2}{*}{1.264} & \multirow{2}{*}{0.207} \\
\hline & $35 \%$ & $30 \%$ & & \\
\hline \multirow{2}{*}{$\begin{array}{c}\text { Disagree: } \\
20 \% \text { of the companies }\end{array}$} & 84 & 35 & \multirow{2}{*}{3.405} & \multirow{2}{*}{0.000} \\
\hline & $25 \%$ & $14 \%$ & & \\
\hline \multirow{2}{*}{ Completely disagree: $2 \%$ of the companies } & 10 & 1 & \multirow{2}{*}{2.306} & \multirow{2}{*}{0.021} \\
\hline & $3 \%$ & $0.1 \%$ & & \\
\hline Chi square & \multicolumn{4}{|c|}{26.981} \\
\hline p-value & \multicolumn{4}{|c|}{0.000} \\
\hline
\end{tabular}

Source: Authors' results

The results presented in the Table 1 show that $45 \%$ of the entrepreneurs agree with the presented statement, while $33 \%$ of them take no position and $22 \%$ disagree with the statement. The presented values of the test criteria confirmed that there are the statistically significant differences in the overall structure of the responses in relation to the motivation for starting a business ( $p$-value $=0.001$ ). There are 
also differences between the affirmative and negative answers between the selected groups in relation to the perception of innovativeness of their companies. Hypothesis H1A is adopted.

The results of the research of issues of development of new products and services between the selected companies are presented in Table 2.

Table 2

We regularly develop new products and services in our enterprise

\begin{tabular}{|c|c|c|c|c|}
\hline \multirow{2}{*}{ Innovativeness } & \multicolumn{2}{|c|}{ Motive for starting a business } & \multirow{2}{*}{ Z-score } & \multirow{2}{*}{$\begin{array}{l}\text { Z-score } \\
\text { p-value }\end{array}$} \\
\hline & Money & Mission & & \\
\hline \multirow{2}{*}{$\begin{array}{c}\text { Completely agree: } 6 \% \text { of the } \\
\text { companies }\end{array}$} & 32 & 5 & \multirow{2}{*}{3.767} & \multirow{2}{*}{0.000} \\
\hline & $10 \%$ & $2 \%$ & & \\
\hline \multirow{2}{*}{$\begin{array}{c}\text { Agree: } \\
40 \% \text { of the companies }\end{array}$} & 149 & 83 & \multirow{2}{*}{2.946} & \multirow{2}{*}{0.003} \\
\hline & $45 \%$ & $33 \%$ & & \\
\hline \multirow{2}{*}{$\begin{array}{l}\text { Take no position: } 23 \% \text { of the } \\
\text { companies }\end{array}$} & 66 & 69 & \multirow{2}{*}{-2.117} & \multirow{2}{*}{0.034} \\
\hline & $20 \%$ & $27 \%$ & & \\
\hline \multirow{2}{*}{$\begin{array}{l}\text { Disagree: } \\
27 \% \text { of the companies }\end{array}$} & 67 & 88 & \multirow{2}{*}{-3.983} & \multirow{2}{*}{0.000} \\
\hline & $20 \%$ & $35 \%$ & & \\
\hline \multirow{2}{*}{$\begin{array}{l}\text { Completely disagree: } 4 \% \text { of the } \\
\text { companies }\end{array}$} & 16 & 6 & \multirow{2}{*}{1.537} & \multirow{2}{*}{0.123} \\
\hline & $5 \%$ & $2 \%$ & & \\
\hline Chi square & \multicolumn{4}{|c|}{35.857} \\
\hline p-value & \multicolumn{4}{|c|}{0.000} \\
\hline
\end{tabular}

Source: Authors' results

The results presented in Table 2 show that 269 entrepreneurs (46\%) agree with the formulated statement, 135 entrepreneurs (23\%) take no position, and 177 entrepreneurs $(31 \%)$ disagree with the statement. P-value confirms the existence of the significant differences in the structure of the responses of the group of entrepreneurs regarding the statement about the development of new products and services in their companies $(p$-value $=0.000)$. Statistically significant differences can be also observed in case of absolutely affirmative and affirmative answers among the surveyed groups of entrepreneurs ( $\mathrm{p}$-value, Zscore $=0.000 ;$ p-value, $Z$-score $=0.003)$. Statistical hypothesis H1B can be rejected.

Table 3

We try to use changes in the target market to be ahead of the competition

\begin{tabular}{|c|c|c|c|c|}
\hline \multirow{2}{*}{ Proactiveness } & \multicolumn{2}{|c|}{ Motive for starting a business } & \multirow{2}{*}{ Z-score } & \multirow{2}{*}{$\begin{array}{l}\text { Z-score } \\
\text { p-value }\end{array}$} \\
\hline & Money & Mission & & \\
\hline \multirow{2}{*}{ Completely agree: $16 \%$ of the companies } & 42 & 49 & \multirow{2}{*}{-2.232} & \multirow{2}{*}{0.026} \\
\hline & $13 \%$ & $19.99 \%$ & & \\
\hline \multirow{2}{*}{$\begin{array}{c}\text { Agree: } \\
59 \% \text { of the companies }\end{array}$} & 191 & 154 & \multirow{2}{*}{-0.845} & \multirow{2}{*}{0.395} \\
\hline & $58 \%$ & $61 \%$ & & \\
\hline \multirow{2}{*}{$\begin{array}{l}\text { Take no position: } \\
19 \% \text { of the companies }\end{array}$} & 72 & 36 & \multirow{2}{*}{2.294} & \multirow{2}{*}{0.022} \\
\hline & $22 \%$ & $14 \%$ & & \\
\hline \multirow{2}{*}{$\begin{array}{c}\text { Disagree: } \\
5 \% \text { of the companies }\end{array}$} & 21 & 11 & \multirow{2}{*}{1.037} & \multirow{2}{*}{0.298} \\
\hline & $6 \%$ & $4 \%$ & & \\
\hline \multirow{2}{*}{ Completely disagree: $1 \%$ of the companies } & 4 & 1 & \multirow{2}{*}{1.051} & \multirow{2}{*}{0.293} \\
\hline & $1 \%$ & $0.01 \%$ & & \\
\hline Chi square & \multicolumn{4}{|c|}{10.891} \\
\hline p-value & \multicolumn{4}{|c|}{0.028} \\
\hline
\end{tabular}

Source: Authors' results 
The results presented in Table 3 show that $436(75 \%)$ of the entrepreneurs agree with the statement that their companies are trying to use social changes to be ahead of the competition, $19 \%$ takes no position, and only $6 \%$ disagrees with this statement. We can confirm statistical hypotheses $\mathrm{H} 2 \mathrm{~A}$ ( $\mathrm{p}$ - value $=0.028)$, but the factor of motivation is independent in case of negative responses ( $\mathrm{Z}$ - score is 1.037).

Table 4

We always try to catch the initiative on the market in order to beat the competition

\begin{tabular}{|c|c|c|c|c|}
\hline \multirow{2}{*}{ Proactiveness } & \multicolumn{2}{|c|}{ Motive for starting a business } & \multirow{2}{*}{ Z-score } & \multirow{2}{*}{$\begin{array}{l}\text { Z-score } \\
\text { p-value }\end{array}$} \\
\hline & Money & Mission & & \\
\hline \multirow{2}{*}{ Completely agree: $10 \%$ of the companies } & 32 & 28 & \multirow{2}{*}{-0.572} & \multirow{2}{*}{0.568} \\
\hline & $10 \%$ & $11 \%$ & & \\
\hline \multirow{2}{*}{$\begin{array}{c}\text { Agree: } \\
55 \% \text { of the companies }\end{array}$} & 170 & 149 & \multirow{2}{*}{$-1,883$} & \multirow{2}{*}{0.060} \\
\hline & $52 \%$ & $59 \%$ & & \\
\hline \multirow{2}{*}{$\begin{array}{l}\text { Take no position: } \\
20 \% \text { of the companies }\end{array}$} & 71 & 45 & \multirow{2}{*}{1.071} & \multirow{2}{*}{0.284} \\
\hline & $22 \%$ & $18 \%$ & & \\
\hline \multirow{2}{*}{$\begin{array}{l}\text { Disagree: } \\
13 \% \text { of the companies }\end{array}$} & 51 & 26 & \multirow{2}{*}{1.794} & \multirow{2}{*}{0.073} \\
\hline & $15 \%$ & $10 \%$ & & \\
\hline \multirow{2}{*}{ Completely disagree: $2 \%$ of the companies } & 6 & 3 & \multirow{2}{*}{0.602} & \multirow{2}{*}{0.548} \\
\hline & $2 \%$ & $1 \%$ & & \\
\hline Chi square & \multicolumn{4}{|c|}{5.962} \\
\hline p-value & \multicolumn{4}{|c|}{0.202} \\
\hline
\end{tabular}

Source: Authors' results

As it is presented in Table 4, 65\% of entrepreneurs agreed with the statement, $20 \%$ took no position and $15 \%$ disagreed with it. When analyzing the responses of the entrepreneurs in accordance with motivation for starting a business, it can be stated that there are no statistically significant differences between these groups of entrepreneurs $(\mathrm{Chi}-$ square $=5.962 ; \mathrm{p}$ - value $=0.202)$, including the ones with affirmative answers. H2B can be adopted. The results allow us to adopt the hypothesis H2B.

Table 5

Our company has a reputation of an aggressive enterprise

\begin{tabular}{|c|c|c|c|c|}
\hline \multirow{2}{*}{ Aggression to competitors } & \multicolumn{2}{|c|}{ Motive for starting a business } & \multirow{2}{*}{ Z-score } & \multirow{2}{*}{$\begin{array}{l}\text { Z-score } \\
\text { p-value }\end{array}$} \\
\hline & Money & Mission & & \\
\hline \multirow{2}{*}{ Completely agree: $2 \%$ of the companies } & 9 & 3 & \multirow{2}{*}{1.286} & \multirow{2}{*}{0.197} \\
\hline & $3 \%$ & $1 \%$ & & \\
\hline \multirow{2}{*}{$\begin{array}{c}\text { Agree: } \\
10 \% \text { of the companies }\end{array}$} & 30 & 29 & \multirow{2}{*}{-0.973} & \multirow{2}{*}{0.332} \\
\hline & $9 \%$ & $12 \%$ & & \\
\hline \multirow{2}{*}{$\begin{array}{c}\text { Take no position: } \\
25 \% \text { of the companies }\end{array}$} & 92 & 51 & \multirow{2}{*}{2.095} & \multirow{2}{*}{0.035} \\
\hline & $28 \%$ & $20 \%$ & & \\
\hline \multirow{2}{*}{$\begin{array}{c}\text { Disagree: } \\
49 \% \text { of the companies }\end{array}$} & 163 & 119 & \multirow{2}{*}{0.474} & \multirow{2}{*}{0.638} \\
\hline & $49 \%$ & $47 \%$ & & \\
\hline \multirow{2}{*}{ Completely disagree: $15 \%$ of the companies } & 36 & 49 & \multirow{2}{*}{-2.909} & \multirow{2}{*}{0.003} \\
\hline & $11 \%$ & $20 \%$ & & \\
\hline Chi square & \multicolumn{4}{|c|}{13.126} \\
\hline p-value & \multicolumn{4}{|c|}{0.010} \\
\hline
\end{tabular}

Source: Authors' results 
The results of the research of the reputation of an aggressive enterprise in Table 5 show that $12 \%$ of the entrepreneurs agree with this statement, $25 \%$ of them stand no position, and $64 \%$ of them do not agree with it, regardless of the motivation for starting a business. The significance of the differences between the responses by the motive for doing business was confirmed ( $\mathrm{p}$-value $=0.010$ ). However, statistically significant differences for the affirmative replies were not found (strongly agree 0.197, agree 0.332). Hypothesis H3A was adopted.

Table 6

Our activities in relation to competition are often aggressive

\begin{tabular}{|c|c|c|c|c|}
\hline \multirow{2}{*}{ Aggression to competitors } & \multicolumn{2}{|c|}{ Motive for starting a business } & \multirow{2}{*}{ Z-score } & \multirow{2}{*}{$\begin{array}{l}\text { Z-score } \\
\text { p-value }\end{array}$} \\
\hline & Money & Mission & & \\
\hline \multirow{2}{*}{ Completely agree: $2 \%$ of the companies } & 12 & 1 & \multirow{2}{*}{2.614} & \multirow{2}{*}{0.009} \\
\hline & $4 \%$ & $0 \%$ & & \\
\hline \multirow{2}{*}{$\begin{array}{c}\text { Agree: } \\
13 \% \text { of the companies }\end{array}$} & 47 & 28 & \multirow{2}{*}{1.099} & \multirow{2}{*}{0.271} \\
\hline & $14 \%$ & $11 \%$ & & \\
\hline \multirow{2}{*}{$\begin{array}{c}\text { Take no position: } \\
20 \% \text { of the companies }\end{array}$} & 60 & 53 & \multirow{2}{*}{-0.885} & \multirow{2}{*}{0.379} \\
\hline & $18 \%$ & $21 \%$ & & \\
\hline \multirow{2}{*}{$\begin{array}{l}\text { Disagree: } \\
53 \% \text { of the companies }\end{array}$} & 183 & 126 & \multirow{2}{*}{1.257} & \multirow{2}{*}{0.207} \\
\hline & $55 \%$ & $50 \%$ & & \\
\hline \multirow{2}{*}{ Completely disagree: $12 \%$ of the companies } & 28 & 43 & \multirow{2}{*}{-3.152} & \multirow{2}{*}{0.001} \\
\hline & $8 \%$ & $17 \%$ & & \\
\hline Chi square & \multicolumn{4}{|c|}{17.825} \\
\hline p-value & \multicolumn{4}{|c|}{0.001} \\
\hline
\end{tabular}

Source: Authors' results

Only $15 \%$ of entrepreneurs agreed with the analyzed statement, while $20 \%$ did not take any position, and 65\% disagreed. Test criteria results confirm the differences between the groups in accordance with the motivation to start up a business (Chi-square $=17.825$, $\mathrm{p}$-value $=0.001$ ). The hypothesis H3B was adopted.

Our positive results on innovativeness and proactiveness are in line with the authors which support the importance of EO for SMEs (e. g. Moreno \& Casillas, 2008; Lumpkin \& Dess, 1996; Laforet, 2013; Avlonitis \& Salavou, 2007; Kraus et al., 2012). On the other hand our results didn't confirm the opinions focusing on the importance of competitive aggressiveness (e. g. Moreno \& Casillas, 2008; Ireland et al., 2003). Nevertheless, our results are not always supported at the prescribed level of significance, but we were able to identify the firm level differences in a majority of the cases.

Our results suggest that the entrepreneurs perceiving doing business as a mission act less aggressively against the competition. Our results also suggest that different entrepreneurial motives can be the factor that causes differences in attitude to EO.

It is true, that most of the total number of researched entrepreneurs were motivated by money (330), we consider the finding, that the number of people, who are doing business due to non-financial motives, is a positive finding for the society. As we found a substantial number of the entrepreneurs feels the need to leave a trail for a future generation. Conversely, others do the business because they continue in the mission of their family predecessors.

The findings of statistically significant differences in the attitude to identified constructs of EO caused by different entrepreneurial motives confirm the results of Boada-Grau et al. (2016) that different entrepreneurial motives can cause different entrepreneurial behavior (in our case different attitude to EO). 
A good financial stability is definitively the most important for company's survival. While preparing the programs aiming to support the start up of the new businesses the government should also consider the fact that some potential entrepreneurs are driven also by non-financial motives for doing business, and that the entrepreneurs who deal with the environment do not show different results. Creating programs for the support of entrepreneurship of different interest groups (e. g. improvement of the environment, charitable projects, assistance to people who need help) could be a way how to decrease unemployment in the Czech Republic. Support of SMEs in the macroeconomic and regional policy should be complemented by a local government, which is responsible for supplementing a higher level policyand creating suitable conditions and supportive environment for business entities prospering in the town and commune (Adamowicz \& Machla, 2016).

\section{CONCLUSION}

The aim of this article was to identify the relationship between entrepreneurial motives and selected constructs of EO (innovativeness, proactiveness and competitive aggressiveness) in the SMEs sector in the Czech Republic. At the same time it brings interesting findings about the motives for entrepreneurship and practical implications for better understanding how to motivate people who think about doing business to actually start doing it.

Our results showed that the entrepreneurs, consider innovativeness and proactiveness to be important for their businesses regardless the entrepreneurial motives because the number of the affirmative replies was dominating in all the questions related to the innovativeness ( $45 \%$ of respondents consider their company to be innovative, $46 \%$ regularly develop new products and services) and also to proactiveness $(75 \%$ of the respondents try to use the expected changes in target markets to be ahead of the competition, $65 \%$ of them is trying to seize the initiative in order to overtake the competition). Statistically significant differences between the defined two groups were identified in a vast majority of questions (except the question relating to seizing of the initiative in order to overtake the competition). On the other hand, the results showed that regardless the entrepreneurial motives the researched entrepreneurs seem to have non-aggressive strategy against the competition because most of them didn't agree with the statements relating to competitive aggressiveness $(64 \%$ of the respondents does not consider their enterprise to be aggressive, $75 \%$ of them does not carry out aggressive activities against the competition). In general, we have found statistically significant differences between two monitored groups in all cases except for the perception of their enterprise as an aggressive enterprise. Disagreement with the aggressive attitude to competition was presented statistically more often in the group of entrepreneurs motivated by mission compared to entrepreneurs motivated by money.

We are aware of some limitations of this research (e. g. unequal number of men and women or respondents due to the regions of the Czech Republic, limited sample and predominantly regional character of conclusions).

Despite this fact we believe that our article has brought interesting findings and new incentives for further research e. g. of other motives for starting a business in relation to constructs of EO or of other constructs of EO due to entrepreneurial motives). Our results can be useful for practical use for the government and other groups of interest (e. g. The Association of SMEs) when searching and defining the appropriate forms of financial and other support for starting a business and good performance in SME sector. Czech government represented by its institutions (in this case especially by Ministry of Industry and Trade of the Czech Republic) responsible for creating conditions of entrepreneurship can use this data as background for both improvement conditions for entrepreneurship and finding ways of better motivation for starting a business. 


\section{REFERENCES}

Adamowicz, M., \& Machla, A. (2016). Small and Medium Enterprises and the Support Policy of Local Government. Oeconomia Copernicana, 7(3), 405-437. doi: http://dx.doi.org/10.12775/OeC.2016.024

Avlonitis, G. J., \& Salavou, H. E. (2007). Entrepreneurial orientation of SMEs, product innovativeness, and performance. Journal of Business Research, 60(5). doi: https://doi.org/10.4018/ijbir.2015070102

Belás J., \& Sopková G. (2016a). Significant determinants of the competitive environment for SMEs in the context of financial and credit risks. Journal of International Studies, 9(2), 139-149. doi: http://dx.doi.org/10.14254/2071$\underline{8330.2016 / 9-2 / 10}$

Belás, J., Sopková, G. (2016b). A Model of Entrepreneurial Orientation. Transformation in Business \& Economics, 15 (2B (38B)), 630-645.

Belás, J., Ključnikov, A., Vojtovič, S., \& Sobeková-Májková, M. (2015). Approach of the SME Entrepreneurs to Financial Risk Management in Relation to Gender and Level of Education. Economics and Sociology, 8(4). https://doi.org/10.14254/2071-789X.2015/8-4/2

Belás, J., Bartoš, P., Ključnikov, A., \& Doležal, J. (2015). Risk perception diff erences between micro-, small and medium enterprises. Journal of International Studies, 7(3), 19-29. doi: http://dx.doi.org/10.14254/2071$\underline{8330.2015 / 8-3 / 2}$

Betakova, J., Haviernikova K., Dvorsky, J. (2014). The issues of clusters potential assessing in the regions of Slovak Republic. Proceedings of $2^{\text {nd }}$ International Conference on Management Innovation and Business Innovation. Lecture Notes in Management Science, 44. doi: http://dx.doi.org/10.5729/lnms.vol44.122

Beugelsdijk, S., Noorderhaven, N. (2005). Personality Characteristics of Self-Employed; An Empirical Study. Small Business Economics, 24(2). doi: http://dx.doi.org/10.1007/s11187-003-3806-3

Boada-Grau, J., Sánchez-García, J. C., Viardot, E., Boada-Cuerva, M., \& Vigil-Colet, A. (2016). Adaption of an entrepreneurial motivation scale into Spanish. Anales de Psicología, 32(2). doi: http://dx.doi.org/10.6018/analesps.32.2.208381

Caliendo, M., Fossen, F., \& Kritikos, A. S. (2014). Personality characteristics and the decisions to become and stay self-employed. Small Bus Econ, 42(4). doi: http://dx.doi.org/10.1007/s11187-013-9514-8

Covin, J. G., Wales, G. (2011). The Measurement of Entrepreneurial Orientation. Entrepreneurship Theory and Practice, 36(4). doi: http://dx.doi.org/10.1111/j.1540-6520.2010.00432.x

Covin, J., Slevin, D. (1989). Strategic Management of Small Firms in Hostile and Benign Environments. Strategic Management Journal, 10(1). doi: http://dx.doi.org/10.1002/smj.4250100107

Dúbravská, M., Mura, L., Kotulič, R., \& Novotný, J. (2015). Internationalization of Entrepreneurship - Motivating Factors: Case Study of the Slovak Republic. Acta Polytechnica Hungarica, 12(5), 121-133. doi : http://dx.doi.org/10.12700/APH.12.5.2015.5.7

Frese, M., \& Gielnik, M. M. (2014). The Psychology of Entrepreneurship. Annual Review of Organizational Psychology and Organizational Behavior, 1(1). doi: http://dx.doi.org/10.1146/annurev-orgpsych-031413-091326

Hines, J. L. (2004). Characteristics of an entrepreneur. Surgical Neurology, 61(4). doi: http://dx.doi.org/10.1016/j.surneu.2003.05.004

Hudakova, M., Buganova, K., \& Dvorsky, J. (2015). Assessment and evaluation of the impact of financial risk on small and medium-sized enterprises in Slovakia. Proceedings of Finance and performance of firms in science, education and practice. Zlin. 442-451. ISBN 978-80-7454-482-8.

Ireland, R. D., Hitt, M. A., \& Sirmon, D. G. (2003). A Model of Strategic Entrepreneurship: The Construct and Its Dimensions. Journal of Management, 29(6). doi: http://dx.doi.org/10.1016/s0149-2063 03 00086-2

Ključnikov, A., Belás, J., Kozubíková, L., \& Paseková, P. (2016). The Entrepreneurial Perception of SME Business Environment Quality in the Czech Republic. Journal of Competitiveness, $8(1)$. https://doi.org/10.7441/joc.2016.01.05

Kozubíková, L., Belás, J., Ključnikov, A., \& Virglerová, Z. (2015). Differences in approach to selected constructs of entrepreneurail orientation in SME segment regarding the selected socio-demographic factors. Transformation in Business nad Economic, 14(3C(36C)), 333-355.

Kraus, S. (2013). The role of entrepreneurial orientation in service firms: empirical evidence from Austria. The Service Industries Journal, 33(5). doi: http://dx.doi.org/10.1080/02642069.2011.622373 
Kraus, S., Rigtering, J. P., Hughes, M., \& Hosman, V. (2012). Entrepreneurial orientation and the business performance of SMEs: a quantitative study from the Netherlands. Review of Managerial Science, 6(2). doi: https://10.1007/s11846-011-0062-9

Laforet, S. (2013). Organizational innovation outcomes in SMEs: Effects of age, size, and sector. Journal of World Business, 48(4). doi: http://dx.doi.org/10.1016/j.jwb.2012.09.005

Lim, S., Envick, B. R. (2013). Gender and entrepreneurial orientation: a multi-country study. Int Entrep Manag J, 9(3). doi: http://dx.doi.org/10.1007/s11365-011-0183-2.

Lumpkin, G. T., Cogliser, C. C., \& Schneider, D. R. (2009). Understanding and measuring autonomy: An entrepreneurial orientation perspective. Entrepreneurship Theory and Practice, 33(1). doi: https://doi.org/10.1111/j.1540-6520.2008.00280.x

Lumpkin, G. T., \& Dess, G. G. (1996). Clarifying the entrepreneurial orientation construct and linking it to performance. Academy of Management Review, 21 (1). doi: http://dx.doi.org/10.5465/amr.1996.9602161568.

Mattis, M. C. (2000). Women entrepreneurs in the United States. In M. J. Davidson \& R. J. Burke, Women in management: current research issues (53-68). Thousand Oaks, CA: Sage. doi: http://dx.doi.org/10.4135/9781446219775.n5

Miller, D. (1983). The correlates of entrepreneurship in three types of firms. Management Science, 29(7). doi: http://dx.doi.org/10.1287/mnsc.29.7.770

Moreno, N. M., \& Casillas, J. C. (2008). Entrepreneurial orientation and growth of SMEs: a casual model. Entrepreneurship Theory and Practice, 32(3). doi: http://dx.doi.org/10.1111/j.1540-6520.2008.00238.x

Petrakis, P. E. (2007). The effects of risk and time on entrepreneurship. International Entrepreneurship and Management Journal, 3(3). doi: https://doi.org/10.1007/s11365-006-0026-8

Pinfold, J. F. (2001). The expectations of new business founders: The New Zealand case. Journal of Small Business Management, 39(3). doi: https://doi.org/10.1111/0447-2778.00025

Rauch, A., Wiklund, J., Lumpkin, G., \& Frese, M. (2009). Entrepreneurial Orientation and Business Performance: An Assessment of Past Research and Suggestions for the Future. Entrepreneurship: Theory and Practice, 33(3). doi: http://dx.doi.org/10.1111/i.1540-6520.2009.00308.x

Rey-Marti, A., Porcar, A. T., \& Mas-Tur, A. (2015). Linking female entrepreneurs' motivation to business survival. Journal of Business Research, 68(4). doi: http://dx.doi.org.proxy.k.utb.cz/10.1016/j.jbusres.2014.11.033

Robichaud, Y., Cachon, J. C., \& Haq, R. (2010). Motives, success factors, and barriers among Canadian female entrepreneurs: The case of Greater Sudbury. Entrepreneurial Practice Review, 1(2).

Virglerova, Z., Dobes, K., \& Vojtovic, S. (2016). The Perception of the State's Influence on its Business Environment in the SMEs from Czech Republic. Administratie si Management Public, 26.

Vojtovič, S. (2016). The Impact of the Structural Funds on Competitiveness of Small and Medium-Sized Enterprises. Journal of Competitiveness, 8(4), 30-45.doi: http://dx.doi.org/ 10.7441/joc.2016.04.02

Wiklund, J., \& Shepherd, D. (2003). Knowledge-based Resources, Entrepreneurial Orientation, and the Performance of Small and Medium Sized Businesses. Strategic Management Journal, 24(13). doi: http://dx.doi.org/10.1002/smj.360

Williams, C. C. (2009). The motives of off-the-books entrepreneurs: necessity- or opportunity-driven? International Entrepreneurship and Management Journal, 5(2). doi: https://doi.org/10.1007/s11365-008-0098-8

Zamecnik, R., \& Vystupova, L. (2012). Research on performance measurement under conditions of Czech enterprises. $7^{\text {th }}$ International Conference on Accounting and Management Information Systems (AMIS). Book Series: Proceedings of the International Conference Accounting and Management Information Systems, 1353-1367

Zastempowski, M., \& Przybylska, N. (2016). Cooperation in Creating Innovation in Polish Small and Medium-Sized Enterprises in the Light of Empirical Studies. Journal of Competitiveness, 8(1), 42-58. doi: http://dx.doi.org/10.7441/joc.2016.02.04

Zortea-Johnston, E., Darroch, J., \& Matear, S. (2012). Business orientation and innovation in small medium sized enterprises. International entrepreneurship Management Journal, 8(2). doi: http://dx.doi.org/10.1007/s11365-011$\underline{0170-7}$ 